\title{
ESTIMATION OF TOTAL BODY SODIUM BY ISOTOPIC DILUTION. I. STUDIES ON YOUNG ADULTS 1, 2,3
}

\author{
By GILBERT B. FORBES * AND ANNE PERLEY \\ (From the Department of Pediatrics, Washington University School of Medicine, and the Saint \\ Louis Children's Hospital, Saint Louis, Mo.)
}

(Submitted for publication December 13, 1950; accepted, March 19, 1951)

Although the amount of sodium contained within the human body has been determined in a number of fetuses and newborns by direct chemical analysis, no such data are available for the adult. This value has been estimated (by means which are not clear) to be $63 \mathrm{Gm}$. by Shohl (2), $56 \mathrm{Gm}$. by Hackh (3), and $105 \mathrm{Gm}$. by Sherman (4) for a $70 \mathrm{Kg}$. man. The literature contains reports of the chemical analysis of one adult carcass, but unfortunately values for sodium are not given (5). The importance of sodium in the electrolyte economy of the human body prompted us to undertake a study of the feasibility of determining total body sodium by the isotopic dilution method.

In vitro applications of isotopic dilution analysis are well known, and present no particular difficulties under conditions wherein the system to be studied is a closed one. The method was applied to man for the determination of total body water in 1934 by Hevesy and Hofer (6) who used deuterium, a stable isotope, in their experiments. More recently radioactive hydrogen has been used for the same purpose (7). Although Kaltreider and his co-workers (8) made the suggestion several years ago that they were measuring total body sodium in experiments aimed at determination of extracellular fluid volume, F. D. Moore (9) was the first to emphasize the potentialities of the isotopic dilution method for the measurement of total body sodium and potassium in addition to total body water in man, and re-

\footnotetext{
1 This work was carried out under grants from the Children's Research Foundation and the U. S. Atomic Energy Commission.

2 The cooperation of the Departments of Neurosurgery and Orthopedic Surgery of the Washington University School of Medicine and of the Cyclotron Group at Washington University is gratefully acknowledged.

8 A preliminary report of these studies has been published elsewhere (1).

4 Present address: Southwestern Medical School, Dallas, Texas.
}

ported a value of 59 meq. of sodium per $\mathrm{Kg}$. in an adult male weighing $66 \mathrm{Kg}$.

This paper reports the result of a study of the measurement of total body sodium (perhaps a more accurate term would be "total exchangeable sodium") in a series of healthy young adults. In brief, the procedure employed was to introduce a known amount of radioactive sodium into the body, allow it to become distributed through the body tissues, and then determine the serum sodium specific activity. ${ }^{5}$ If allowance is made for excretion of radiosodium during the equilibration period, the total amount of sodium in equilibration with radiosodium can then be calculated. It should be pointed out that this method makes no distinction between extracellular and intracellular sodium.

\section{METHODS}

Radioactive sodium ( $\mathrm{Na}^{24}$, half-life 15 hours) was manufactured in the Washington University cyclotron and prepared in our laboratory as a sterile isotonic solution of sodium chloride. Accurately measured volumes were given intravenously according to the method described by Barnett and Fellers (10). The total volume of isotonic saline injected, including the "wash" saline, did not exceed $5 \mathrm{cc}$., corresponding to 0.8 meq. of sodium, an amount negligible in relation to the total body content of sodium. The amount of $\mathrm{Na}^{24}$ used in these experiments varied from 1 to $11 / 2$ microcuries per $\mathrm{Kg}$. of body weight; this quantity has been calculated to deliver a total radiation dose of from 0.11 to 0.17 roentgen equivalent physical (11). Samples of venous blood were obtained from a vein other than that used for injection of radiosodium; serum was separated from the cells within an hour.

Members of the resident house staff and medical students served as subjects for these experiments. They were all in good health and ranged in age from 20 to 34 years. They were allowed normal activity and consumed their usual diet during the experiment, but were instructed to avoid addition of excess salt to their food and to refrain from excessive physical exercise. Samples of normal bone and brain tissue and cerebrospinal fluid were obtained from patients at the time of regularly scheduled operations.

\footnotetext{
${ }^{5}$ Radioactivity per unit weight of sodium.
} 
One cc. amounts of serum, urine, and cerebrospinal fluid, in duplicate, were pipetted into metal planchets, 33 $\mathrm{mm}$. in diameter, and dried at $70^{\circ} \mathrm{C}$. after the addition of one drop of synthetic detergent (Acidolate). Aliquots of the injected solution were similarly prepared in triplicate. The samples were counted with an end-window Geiger tube attached to an autoscaler. Counting periods in most instances were of such length that statistical variations due to random fluctuations of radioactive emission were $\pm 1.6 \%$ (standard deviation) or less for the serum and standard samples, and $\pm 3 \%$ or less for urine samples. ${ }^{6}$ Standard solutions of $\mathrm{Na}^{24}$ were assayed at frequent intervals during each counting run, and a decay curve constructed for each series of determinations; from this curve appropriate decay corrections were made. Coincidence and background effects were also accounted for, and the counter efficiency was checked periodically with a radium $\mathrm{D}-\mathrm{E}$ standard.

Bone and brain samples were obtained in the operating room, care being taken to avoid contamination with saline sponges, blotted on filter paper to remove excess blood, and put immediately in tared stoppered bottles. The tissues were weighed and then digested in nitric acid until the resulting solution was clear; aliquots of this solution were then prepared for counting in one of two ways. In our earlier experiments the solution was transferred to porcelain capsules, dried on an electric hot plate and weighed just prior to counting. Corrections for self-absorption could then be made by reference to a self-absorption curve constructed from assays of beef bone to which known amounts of $\mathrm{Na}^{24}$ had been added. These were prepared in the same manner as the human bone samples and ranged in weight (as plated for counting) from 13 to 292 mg. per square centimeter. In the case of brain tissue selfabsorption corrections were not necessary. Samples of serum for comparison with bone and brain were also plated in porcelain capsules to equalize back-scattering effects. Later in the course of the study counting was done with a thin walled dipping counter, the samples of bone digest and of serum being assayed in liquid form so that selfabsorption corrections were no longer necessary.

Analyses of serum, cerebrospinal fluid, urine, and bone for sodium were carried out by the zinc uranyl acetate gravimetric method (12). Dry, rather than wet ashing was used for the serum. Aliquots of the nitric acid bone digest were evaporated to dryness and ashed in a muffle furnace at $540^{\circ} \mathrm{C}$. The ash was then dissolved in nitric acid, an excess of ammonia added to remove the greater part of the calcium and phosphate, and an aliquot of the filtrate evaporated to dryness. The residue was taken up in water and quantitatively transferred to the zinc uranyl acetate reagent in the usual manner. Analyses of the brain tissue were made by the flame photometer.

For the purpose of chloride analysis, the preliminary nitric acid digestion of bone was made in the presence of silver nitrate, which has been shown, in our laboratory, not to interfere with the gravimetric determination of

- In a few instances counting rates were so low that errors in estimating serum radioactivity were $\pm 3 \%$. sodium. Chloride was determined in serum and bone digest by the modified Volhard-Harvey titration method (13).

Calculations were made as follows: serum was obtained from the subjects at times ranging from 18 to 24 hours (in two, a 17 hour period was used) following the intravenous administration of radiosodium, and urine was collected over the same period of time. Assuming complete distribution of the injected radiosodium, serum specific activity should equal total body specific activity, so that

total exchangeable sodium (TES)

$$
=\frac{\mathrm{Na}^{24} \text { injected }-\mathrm{Na}^{24} \text { excreted }}{\text { serum } \mathrm{Na}^{24} / \text { serum sodium }} \text {. }
$$

No corrections were made for the serum water content, the Donnan effect, or the possibility of slight differences in mobility between $\mathrm{Na}^{24}$ and $\mathrm{Na}^{23}$ ions.

\section{RESULTS}

The results, of 36 determinations of total exchangeable sodium (TES) in 32 healthy young adults are set forth in Table $I$. The average value for males, 41.9 meq. per $\mathrm{Kg}$. of body weight, is surprisingly close to Shohl's estimate of $39 \mathrm{meq}$. per $\mathrm{Kg}$. (2). The range of values is so great that one hesitates to speak of an average value for the average adult male. The spread of values ( 32.3 to 54.1 meq.), which would appear to be too great to be explained solely on experimental error, tends to remain (but to a somewhat less degree) when the calculations are made on the basis of height or surface area. Two separate determinations of TES were made in each of four subjects, but since the intervals between determinations were four to 22 months, they cannot be used to assess experimental errors. A considerable proportion of the body sodium is in skeleton and muscle; since the amount of these two tissues probably varies markedly among individuals of the same weight, the wide range of values noted in Table I might be expected.

The average value for females (39.5 meq. per $\mathrm{Kg}$.) is slightly lower than that for males and this difference persists when the calculations are made on the basis of height and surface area; however, the magnitude of the standard deviations would indicate that the average values for the two groups are not significantly different.

These values represent the amount of sodium within the body which comes into equilibrium with administered radiosodium during the ex- 
TABLE IA

Total exchangeable sodium in adult males

In the subjects indicated by the asterisk two samples of blood, drawn at the times indicated, were analyzed for specific activity and the results averaged.

\begin{tabular}{|c|c|c|c|c|c|c|c|c|c|}
\hline Subject & Age & Weight & Height & Surface area & $\begin{array}{c}\text { Equilibration } \\
\text { period }\end{array}$ & TES & $\begin{array}{l}\text { Meq. } \\
\text { Na per Kg. }\end{array}$ & $\begin{array}{l}\text { Meq. } \\
\mathrm{Na} \text { per } \mathrm{cm} .\end{array}$ & $\begin{array}{l}\text { Meq. } \\
\text { Na per } m^{2}\end{array}$ \\
\hline 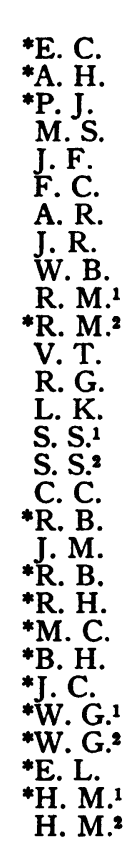 & $\begin{array}{c}\text { years } \\
23 \\
28 \\
24 \\
25 \\
29 \\
33 \\
26 \\
29 \\
27 \\
23 \\
25 \\
34 \\
24 \\
27 \\
25 \\
25 \\
24 \\
28 \\
24 \\
24 \\
27 \\
23 \\
25 \\
29 \\
24 \\
25 \\
24 \\
29 \\
29\end{array}$ & $\begin{array}{c}K_{g} . \\
100 \\
91.6 \\
84.8 \\
83.8 \\
79.8 \\
79.3 \\
77.6 \\
76.9 \\
76.2 \\
75.6 \\
75.4 \\
75.4 \\
75.4 \\
74.4 \\
74.1 \\
75.2 \\
74.1 \\
73.9 \\
73.9 \\
73.5 \\
72.9 \\
71.9 \\
71.8 \\
70.2 \\
69.1 \\
68.1 \\
69.8 \\
58.3 \\
60.6\end{array}$ & $\begin{array}{l}c m . \\
193 \\
193 \\
180 \\
178 \\
170 \\
182 \\
177 \\
177 \\
183 \\
172 \\
172 \\
171 \\
188 \\
178 \\
183 \\
183 \\
180 \\
190 \\
180 \\
176 \\
166 \\
175 \\
182 \\
168 \\
190 \\
189 \\
178 \\
164 \\
164\end{array}$ & $\begin{array}{c}m^{2} \\
2.30 \\
2.22 \\
2.04 \\
2.00 \\
1.91 \\
1.98 \\
1.94 \\
1.93 \\
1.97 \\
1.88 \\
1.88 \\
1.87 \\
2.00 \\
1.91 \\
1.95 \\
1.96 \\
1.93 \\
1.99 \\
1.92 \\
1.99 \\
1.80 \\
1.86 \\
1.91 \\
1.79 \\
1.94 \\
1.92 \\
1.86 \\
1.62 \\
1.65\end{array}$ & $\begin{array}{l}\quad \text { hrs. } \\
23 \\
22 \frac{1}{2} \\
22 \frac{1}{2} \\
19 \frac{1}{2} \\
19 \frac{3}{2} \\
17 \\
23 \\
24 \\
19 \frac{1}{2} \\
20 \\
18-19 \frac{1}{2} \\
24 \\
22 \frac{1}{2} \\
22 \frac{3}{2} \\
23 \\
17 \frac{1}{2} \\
19 \frac{1}{2} \\
22 \frac{1}{2} \\
24 \\
23 \\
18-24 \\
17-22 \frac{1}{2} \\
22 \frac{1}{2} \\
18-22 \\
18-21 \frac{1}{2} \\
18 \frac{1}{2} \\
18-23 \frac{1}{2} \\
22 \\
20\end{array}$ & $\begin{array}{l}\text { meq. } \\
3230 \\
3955 \\
2753 \\
3125 \\
2805 \\
2815 \\
3195 \\
3315 \\
3210 \\
2987 \\
3051 \\
3180 \\
3785 \\
2907 \\
3700 \\
3525 \\
3060 \\
3445 \\
3515 \\
2560 \\
2978 \\
3075 \\
2440 \\
2748 \\
3263 \\
3685 \\
3300 \\
2753 \\
2487\end{array}$ & $\begin{array}{l}32.3 \\
43.2 \\
32.5 \\
37.2 \\
35.1 \\
35.5 \\
41.2 \\
43.1 \\
42.1 \\
39.5 \\
40.4 \\
42.2 \\
50.2 \\
39.1 \\
49.9 \\
46.9 \\
41.3 \\
46.6 \\
47.6 \\
34.8 \\
40.8 \\
42.8 \\
34.0 \\
39.1 \\
47.2 \\
54.1 \\
47.3 \\
47.2 \\
41.1\end{array}$ & $\begin{array}{l}16.7 \\
20.5 \\
15.3 \\
17.6 \\
16.5 \\
15.4 \\
18.0 \\
18.7 \\
17.5 \\
17.4 \\
17.7 \\
18.6 \\
20.1 \\
16.3 \\
20.2 \\
19.3 \\
17.0 \\
18.1 \\
19.5 \\
14.6 \\
17.9 \\
17.6 \\
13.4 \\
16.4 \\
17.2 \\
19.5 \\
18.6 \\
16.8 \\
15.2\end{array}$ & $\begin{array}{l}1405 \\
1780 \\
1350 \\
1562 \\
1470 \\
1420 \\
1645 \\
1715 \\
1630 \\
1590 \\
1623 \\
1700 \\
1895 \\
1520 \\
1898 \\
1800 \\
1585 \\
1730 \\
1830 \\
1355 \\
1653 \\
1650 \\
1280 \\
1535 \\
1680 \\
1930 \\
1775 \\
1698 \\
1518\end{array}$ \\
\hline \multicolumn{7}{|c|}{$\begin{array}{l}\text { Average } \\
\text { Standard deviation } \\
\text { Coefficient of variation }\end{array}$} & $\begin{array}{l}41.9 \\
5.6 \\
13.4 \%\end{array}$ & $\begin{array}{l}17.5 \\
1.46 \\
8.3 \%\end{array}$ & $\begin{array}{l}1628 \\
170 \\
10.5 \%\end{array}$ \\
\hline
\end{tabular}

perimental period. The relation of this value, radiosodium was administered orally rather than "total exchangeable sodium," to the actual quan- intravenously. The values for total body sodium tity of sodium in the body will be discussed below. in these subjects were 29.9 and 23.7 meq. per $\mathrm{Kg}$.,

In two subjects (not included in Table I) respectively, and were so much lower than those

TABLE IB

Total exchangeable sodium in adult females

In the subjects indicated by the asterisk two samples of blood, drawn at the times indicated, were analyzed for specific activity and the results averaged.

\begin{tabular}{|c|c|c|c|c|c|c|c|c|c|}
\hline Subject & Age & Weight & Height & Surface area & $\begin{array}{c}\text { Equilibration } \\
\text { period }\end{array}$ & TES & $\begin{array}{l}\text { Meq. } \\
\text { Na per Kg. }\end{array}$ & $\begin{array}{l}\text { Meq. } \\
\text { Na per cm. }\end{array}$ & $\begin{array}{l}\text { Meq. } \\
\text { Na per } m^{2}\end{array}$ \\
\hline $\begin{array}{l}\text { *R. C. } \\
\text { *D. B. } \\
\text { H. W. } \\
\text { *M. } \dot{\text { K. }} . \\
\text { F. D. } \\
\text { H. H. } \\
\text { M. G. }\end{array}$ & $\begin{array}{c}\text { years } \\
26 \\
20 \\
27 \\
24 \\
25 \\
24 \\
27\end{array}$ & \begin{tabular}{c}
\multicolumn{1}{c}{$\boldsymbol{K g}}$. \\
81.6 \\
62.6 \\
61.3 \\
57.7 \\
55.9 \\
54.4 \\
51.8
\end{tabular} & $\begin{array}{l}c m . \\
171 \\
169 \\
165 \\
162 \\
163 \\
164 \\
162\end{array}$ & $\begin{array}{l}m^{2} \\
1.93 \\
1.71 \\
1.66 \\
1.60 \\
1.59 \\
1.58 \\
1.53\end{array}$ & $\begin{array}{l}\text { hrs. } \\
18-22 \\
18-20 \\
18 \\
18-20 \\
18 \\
23 \\
18\end{array}$ & $\begin{array}{c}\text { meq. } \\
2913 \\
2549 \\
2255 \\
2295 \\
2265 \\
2335 \\
2153\end{array}$ & $\begin{array}{l}35.7 \\
40.7 \\
36.8 \\
39.8 \\
40.6 \\
41.1 \\
41.6\end{array}$ & $\begin{array}{l}17.0 \\
15.1 \\
13.7 \\
14.2 \\
13.9 \\
13.6 \\
13.3\end{array}$ & $\begin{array}{l}1509 \\
1490 \\
1358 \\
1432 \\
1427 \\
1413 \\
1405\end{array}$ \\
\hline \multicolumn{7}{|c|}{$\begin{array}{l}\text { Average } \\
\text { Standard deviation } \\
\text { Coefficient of variation }\end{array}$} & $\begin{array}{l}39.5 \\
2.29 \\
5.8 \%\end{array}$ & $\begin{array}{l}14.4 \\
1.28 \\
8.9 \%\end{array}$ & $\begin{array}{c}1433 \\
51.4 \\
3.6 \%\end{array}$ \\
\hline
\end{tabular}


found in any of the subjects given radiosodium intravenously that attempts to use the oral route of administration were quickly abandoned.

\section{DISCUSSION}

Assumptions. For the purpose of these experiments several assumptions had to be made. First, our subjects were considered to be in sodium balance. For that reason, they were encouraged to engage in normal activity and to eat their usual diet. Experiments were not done during the hot weather. Since radiosodium equilibration would be disturbed by states of either positive or negative sodium balance, every effort was made to avoid change in living habits during the experiment. The prerequisite of a relatively stable sodium economy would appear to preclude the use of this method in the study of some disease states, and would suggest that errors might be introduced by requiring the subjects to fast during the experiment. Secondly, fecal and cutaneous losses of radiosodium were considered to be negligible. No studies of fecal or cutaneous excretion of radiosodium are available in the literature; however, the major pathway of sodium excretion is by way of the kidney. In children, Macy (14) found that only $2 \%$ of the total sodium excretion was by way of the gastrointestinal tract. In our experiments the quantity of radiosodium excreted in the urine during the equilibration period averaged $5.6 \%$ of the injected dose, with a range of 2.7 to $10.1 \%$. Since fecal and cutaneous losses of radiosodium could hardly represent more than a small fraction of the urinary loss (assuming that $\mathrm{Na}^{24}$ is handled by the body similarly to $\mathrm{Na}^{23}$ ), only a small error is incurred in the final results by their omission. None of our subjects perspired profusely or had loose stools during the experimental period.

Thirdly, the sodium turnover during the equilibration period was considered to be small in relation to the total sodium content of the body. Measurements of urinary sodium excretion were made in 11 of our subjects, and ranged from 76.9 to 360 meq., or 2.7 to $12 \%$ (average $5.2 \%$ ) of the calculated total body sodium.

Lastly, is the administered radiosodium in equilibrium with all of the body sodium? Information on this point is largely indirect since no direct chemical analyses of adults are available with which to compare our data.

Change in apparent volume of distribution of $\mathrm{Na}^{24}$ with time. One means of attacking the problem of radiosodium mixing is through a study of the change in radiosodium "space" with time. Although Burch and co-workers (15) have made an exhaustive study of the curve of serum radioactivity at periods up to an hour and Kaltreider and co-workers (8) have extended the period of observation to 12 hours after radiosodium administration, data are lacking for later periods. Figure 1 presents our data in regard to this question. In it are plotted the total radiosodium spaces calculated as

$\underline{\text { radioactivity injected - radioactivity excreted }}$ radioactivity/cc. serum

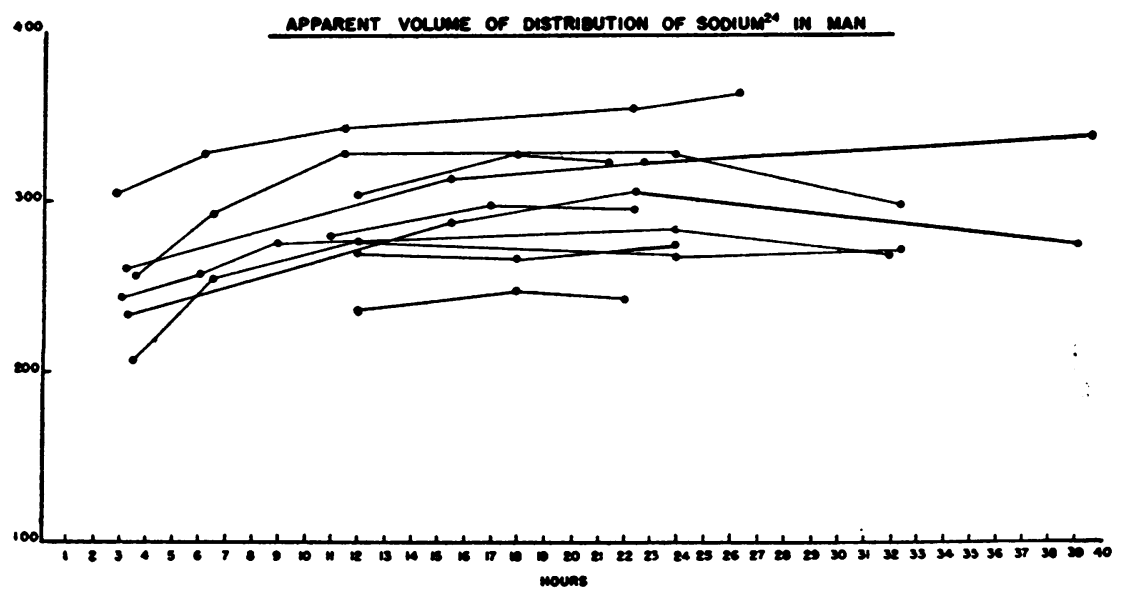

Fig. 1. Curves of Apparent Volume of Na" Distribution, or Sodium "Space" (cc. per KG.) in 10 Adult Subjects on a Normal Diet 


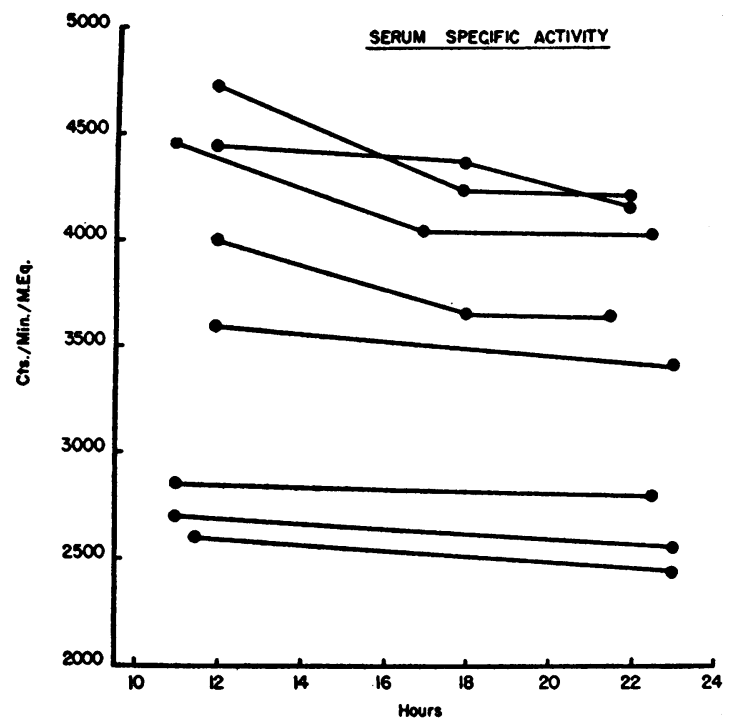

Fig. 2. Curves of Serum Specific Activity, Counts per Minute per meq. Na, in Eight Adult Subjects on a Normal Diet

in 10 adults at times ranging from $2 \frac{1}{2}$ to $391 / 2$ hours after injection. The irregularities in the curves occurring after 30 hours are probably the result of errors due to extremely low counting rates. It is seen that by 18 hours the apparent volume of radiosodium distribution has become fairly stable. Additional exchange after this period occurs at an extremely slow rate. Some of the increase may possibly be due to extra-renal $\mathrm{Na}^{24}$ losses not accounted for in our experiments.

In Figure 2 data on change of serum specific activity during the 11-23 hour period following radiosodium administration are presented for eight subjects. A definite leveling off of the curves is seen to occur by 18 hours.

One possible source of error in these experiments has to do with the fact that injected sodium undoubtedly mixes with dietary sodium taken during the course of the experiment (16). To minimize effects of dietary sodium, four additional subjects (not included in Table I) were studied on a low sodium diet. They took all of their food and fluids under the supervision of the dietitian at the St. Louis Children's Hospital, and consumed a diet adequate in every respect save sodium. The calculated amount of sodium in the food actually consumed varied from 8.52 to 15.9 meq. per day. After three days of the diet, radiosodium was given intravenously and the curve

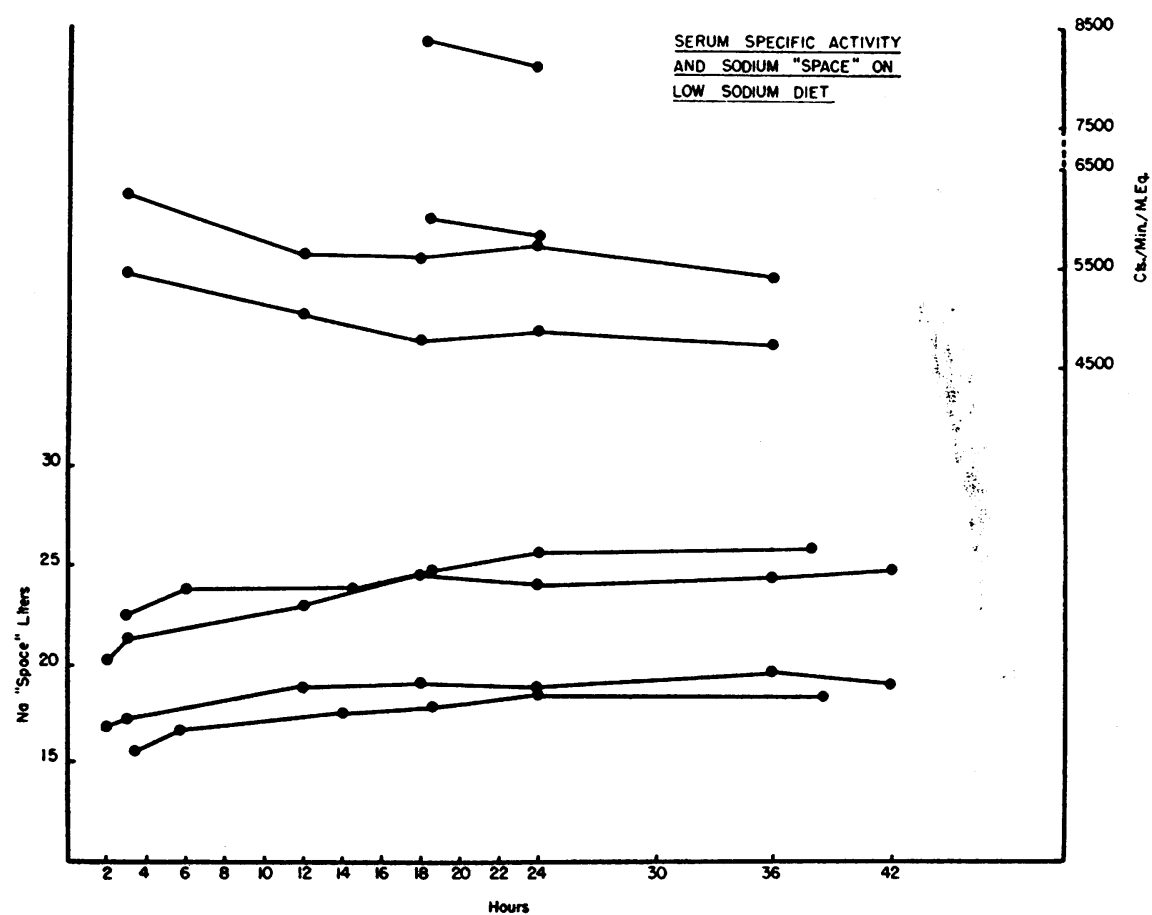

Fig. 3. Curves of Na" "Space" (Liters) and of Serum Specific Activity (Counts per Minute per meq. Na) in Four Subjects Who Were Consuming a Low Sodrum DreT 
of $\mathrm{Na}^{24}$ equilibration determined in the usual way, the diet being continued for the duration of the study period. On such a regime urinary sodium excretion (after the first two days) ranged from 13.2 to 27.2 meq. daily and radiosodium excretion was greatly reduced, ranging from 0.5 to $0.7 \%$ of the administered dose in 24 hours. Thus a situation in which sodium turnover within the body was reduced to a minimum was produced. The curves of these data, presented in Figure 3, are quite similar to the previous ones: we may therefore conclude that dietary sodium in usual amounts does not appreciably disturb radiosodium equilibration. Larger amounts of radiosodium (approximately 2 microcuries per $\mathrm{Kg}$.) were used in these experiments, so that the period of accurate observation could be prolonged.

It was on the basis of these observations that the 18-24 hour period was selected as being most suitable for total body sodium determinations.
Tissue distribution of radiosodium. Studies in animals have shown that there are at least two types of tissue present in the body, when a classification is made on the basis of the rapidity with which radiosodium mixes with tissue sodium. Certain tissues such as muscle, skin, kidney, and liver equilibrate very rapidly (within 20-60 minutes), whereas in others-bone, brain, and testis -mixing may not be complete for at least 12 hours after radiosodium administration (17). The data of Kaltreider and his associates (8) included studies of human pleural, ascitic and spinal fluid and indicated that nine to 12 hours were required for complete mixing in these compartments. However, since pleural and ascitic effusions represent abnormal fluid collections, normal extracellular fluid may well equilibrate at a different rate (probably more rapidly) than these figures would indicate. That abnormal subjects are unsuitable for tissue equilibration studies is

TABLE II

Tissue specific activity

\begin{tabular}{|c|c|c|c|c|c|c|}
\hline Subject & Age & Source & $\begin{array}{l}\text { Time } \\
\text { hours }\end{array}$ & $\begin{array}{l}\text { Sodium content } \\
\text { mg. per Gm. } \\
\text { wet tissue }\end{array}$ & $\begin{array}{c}\text { Ratio } \\
\text { tissue/serum } \\
\text { specific activity }\end{array}$ & $\begin{array}{c}\text { Ratio } \\
\text { tissue/serum } \\
\text { chloride }\end{array}$ \\
\hline
\end{tabular}

Bone

\begin{tabular}{|c|c|c|c|c|c|c|}
\hline Sa. & $37 \mathrm{yr}$. & lumbar lamina & 2 & 2.70 & 0.432 & \\
\hline C. & $44 \mathrm{yr}$. & rib & 4 & 4.95 & 0.169 & 0.198 \\
\hline H. & $76 \mathrm{yr}$. & skull & $6 \frac{1}{2}$ & 5.85 & 0.196 & \\
\hline M. & $11 \mathrm{yr}$. & humerus $\left\{\begin{array}{l}\text { cortical } \\
\text { cancellous }\end{array}\right.$ & $\begin{array}{l}10 \\
10\end{array}$ & $\begin{array}{l}4.66 \\
2.6\end{array}$ & $\begin{array}{l}0.395 \\
0.470\end{array}$ & \\
\hline J. & $51 \mathrm{yr}$. & skull & 16 & 6.35 & 0.188 & \\
\hline Sb. & $22 \mathrm{yr}$. & $\begin{array}{l}\text { femur } \\
\text { tibia }\end{array}$ & $\begin{array}{l}16 \\
16\end{array}$ & $\begin{array}{l}5.94 \\
6.18\end{array}$ & $\begin{array}{l}0.304 \\
0.219\end{array}$ & $\begin{array}{l}0.168 \\
0.244\end{array}$ \\
\hline F. & $37 \mathrm{yr}$. & iliac crest & 20 & 3.17 & 0.398 & \\
\hline P. & $67 \mathrm{yr}$. & lumbar spinous process & 22 & 4.3 & 0.382 & \\
\hline
\end{tabular}

Brain

\begin{tabular}{l|l|l|l|l|l|l}
\hline L. & $46 \mathrm{yr}$. & frontal lobe & $18 \frac{1}{2}$ & 2.12 & 0.600 & \\
\hline
\end{tabular}

Cerebrospinal Fluid

\begin{tabular}{c|c|l|c|c|c|c}
\hline Sc. & $32 \mathrm{yr}$. & ventricle & 11 & * $^{*}$ & 0.967 \\
\hline B. & $8 \mathrm{mo}$. & lumbar & 20 & 3.305 & 0.953 \\
\hline G. & $54 \mathrm{yr}$. & ventricle & 20 & 3.320 & 1.005 & - \\
\hline
\end{tabular}
be 1.05

* Aliquot for sodium determination lost; specific activity calculated assuming ratio of spinal fluid/serum sodium to 
suggested by a comparison of spinal fluid equilibration in subjects with normal and with elevated spinal fluid pressure; mixing was definitely delayed in the latter. In three normal subjects CFS/serum specific activity ratios ranged from 0.953 to 1.005 in the 11-20 hour period following radiosodium injection (see Table II), whereas in two subjects with increased intra-cranial pressure the ratio was 0.431 and 0.667 at the $12-161 / 2$ hour period.

Since studies in animals have revealed that radiosodium comes into equilibrium rather slowly with bone and brain sodium, and since the human skeleton is said to contain approximately $30 \%$ of the total sodium in the body (2), it was decided to study these two tissues. If equilibration is complete in bone and brain, it is presumably complete in other tissues. We are able to obtain only one specimen of normal brain tissue (at time of prefrontal lobotomy), but several specimens of bone were obtained at varying periods of time following radiosodium injection. Data with regard to bone, brain, and spinal fluid specific activity are presented in Table II. If chloride "space" may be taken as a measure of extracellular fluid in bone, our findings indicate that radiosodium mixes quite rapidly (within two hours) with the extracellular sodium of bone and confirm the results published by Kaltreider and his co-workers $(8)$; however, our data indicate that it does not exchange readily with the remainder of the bone sodium. Definite conclusions would seem unwarranted in the face of so much scatter in the data, except to say that probably $40 \%$ of bone sodium exchanges with $\mathrm{Na}^{24}$ over the period studied. Although the single value for brain specific activity is difficult to interpret, there seems to be no doubt that equilibration of $\mathrm{Na}^{24}$ is complete in cerebrospinal fluid by $18-24$ hours.

We present the data on bone with some hesitation because of the technical difficulties involved in the determination of bone sodium and the fact that there are so few published values with which to compare results. Everything possible was done to avoid contamination of the specimens at the operating table, yet the fondness of the surgeons for saline may have thwarted our efforts in some instances. Several of the samples came from elderly people and perhaps radiosodium mixing may occur more readily in the younger individuals who comprise the real subject material of this paper. Taken at face value, radiosodium equilibration in bone, except for sodium present in the chloride "space," must be extremely slow, and probably little could be gained, as far as total body sodium measurement is concerned, in prolonging the equilibration period beyond 1824 hours. The short half-life of $\mathrm{Na}^{24}$ would not permit the use of equilibration periods much longer than this without using larger doses and consequently delivering more radiation to the subject. Perhaps a large portion of bone sodium is truly "fixed," as the experiments of Harrison (18) would indicate, and not readily available for use in body fluid economy. Unfortunately, the literature contains no information on specific activity of bone sodium for comparison with ours. Since $30 \%$ of the total body sodium is said to be in bone (2), these data would suggest that about $82 \%$ of the total body sodium is measured by our method. ${ }^{7}$

The isotopic dilution method, therefore, measures that portion of the total body sodium which is most intimately concerned with the body fluid framework. "Exchangeable sodium," then, represents "mobile" or metabolically active sodium as contrasted to the structural sodium of the skeleton. Further study is needed to determine the exact magnitude of the non-exchangeable portion of the body sodium and the precise relationship of TES to total body sodium in man.

\section{SUM MARY}

1) Measurements of total "exchangeable sodium" in 32 healthy young adults by the isotopic dilution method (utilizing radiosodium ${ }^{24}$ ) revealed an average value of 41.9 meq. and 39.5 meq. per $\mathrm{Kg}$. of body weight for males and females, respectively, with a range of from 32 to 54 meq. per $\mathrm{Kg}$. in males and from 36 to $42 \mathrm{meq}$. in females.

2) An 18-24 hour equilibration period following $\mathrm{Na}^{24}$ administration was selected as optimum on the basis of $(a)$ the shape of the equilibration curve and $(b)$ tissue studies.

\footnotetext{
7 Brain contains only $3 \%$ of the body sodium (2).
} 
3) Determination of sodium specific activity in bone suggests that as much as $60 \%$ of the skeletal sodium may be metabolically inert, for it does not exchange with $\mathrm{Na}^{24}$ during the equilibration period.

4) It was decided to designate the measured quantity as total "exchangeable sodium." The isotopic dilution method, therefore, measures that portion of the body sodium most intimately concerned with fluid balance. By indirect means, it was estimated that TES represents at least $82 \%$ of the actual amount of sodium in the adult body.

\section{REFERENCES}

1. Forbes, G. B., and Perley, A. M., Determination of total body sodium in man with radiosodium. (Proc. Central Soc. Clin. Research), J. Lab. \& Clin. Med., 1949, 34, 1599.

2. Shohl, A. T., Mineral Metabolism. Reinhold Publishing Co., New York, 1939.

3. Hackh, I. W. D., Bioelements: the chemical elements of living matter. J. Gen. Physiol., 1919, 1, 429.

4. Sherman, H. C., Chemistry of Food and Nutrition. Macmillan Co., New York, 1946, 7th edition.

5. Mitchell, H. H., Hamilton, T. S., Steggerda, F. R., and Bean, H. W., The chemical composition of the adult human body and its bearing on the biochemistry of growth. J. Biol. Chem., 1945, 158, 625.

6. von Hevesy, G., and Hofer, E., Die Verweilzeit des Wassers im menschlichen Körper, untersucht mit Hilfe von "schwerem" Wasser als Indicator. Klin. Wchnschr., 1934, 13, 1524.

7. Pace, N., Kline, L., Schachman, H. K., and Harfenist, M., Studies on body composition. IV. Use of radio- active hydrogen for measurement in vivo of total body water. J. Biol. Chem., 1947, 168, 459.

8. Kaltreider, N. L., Meneely, G. R., Allen, J. R., and Bale, W. F., Determination of the volume of the extracellular fluid of the body with radioactive sodium. J. Exper. Med., 1941, 74, 569.

9. Moore, F. D., Determination of total body water and solids with isotopes. Science, 1946, 104, 157.

10. Barnett, H. L., and Fellers, F. X., A simple quantitative method for intravenous injection of small volumes of fluid. Science, 1947, 106, 401.

11. Marinelli, L. D., Quimby, E. H., and Hine, G. J., Dosage determination with radioactive isotopes. II. Practical consideration in therapy and protection. Am. J. Roentgenol., 1948, 59, 260.

12. Butler, A. M., and Tuthill, E., An application of the uranyl zinc acetate method for determination of sodium in biological material. J. Biol. Chem., 1931, 93, 171.

13. Peters, J. P., and Van Slyke, D. D., Quantitative Clinical Chemistry. Vol. II. Methods. Williams \& Wilkins, Baltimore, 1932.

14. Macy, I. G., Principal mineral elements in nutrition, in Handbook of Nutrition. A. M. A., Chicago, 1943.

15. Burch, G., Reaser, P., and Cronvich, J., Rates of sodium turnover in normal subjects and in patients with congestive heart failure. J. Lab. \& Clin. Med., 1947, 32, 1169.

16. Montgomery, M. L., Sheline, G. E., and Chaikoff, I. L., Elimination of sodium in pancreatic juice as measured by radioactive sodium. Am. J. Physiol., 1941, 131, 578.

17. Manery, J. F., and Bale, W. F., The penetration of radioactive sodium and phosphorus into the extraand intracellular phases of tissues. Am. J. Physiol., 1941, 132, 215.

18. Harrison, H. E., The sodium content of bone and other calcified material. J. Biol. Chem., 1937, 120, 457. 